\title{
Phenotypic Characterization of Potato Late Blight Resistance Mediated by the Broad-Spectrum Resistance Gene $R B$
}

\author{
Yu Chen and Dennis A. Halterman
}

First and second authors: Department of Plant Pathology, University of Wisconsin-Madison, Madison 53706; and second author: U.S. Department of Agriculture-Agricultural Research Service, Vegetable Crops Research Unit, Madison, WI 53706. Accepted for publication 24 September 2010.

\section{ABSTRACT}

Chen, Y., and Halterman, D. A. 2011. Phenotypic characterization of potato late blight resistance mediated by the broad-spectrum resistance gene $R B$. Phytopathology 101:263-270.

The potato gene $R B$, cloned from the wild potato species Solanum bulbocastanum, confers partial resistance to late blight, caused by the oomycete pathogen Phytophthora infestans. In order to better characterize this partial resistance phenotype, we have compared host resistance responses mediated by $R B$ with those mediated by the $S$. demissum-derived $R$ gene $R 9$, which confers immunity to $P$. infestans carrying the corresponding avirulence gene $a v r R 9$. We found that both $R B$ and $R 9$ genes were capable of eliciting a hypersensitive cell death response (HR). However, in $R B$ plants, the pathogen escaped HR lesions and continued to grow beyond the inoculation sites. We also found that

Coevolution between pathogens and plants has led to the development of a range of constitutive and inducible resistance mechanisms that help plants survive pathogen attack. The first layer of plant defense, basal defense, relies on the recognition of conserved microbial-associated molecular patterns (MAMPs) by host receptors (31). However, basal defense can be suppressed by pathogen proteins, termed effectors, that are delivered into plant cells, leading to host susceptibility $(23,42)$. Plants have evolved a second layer of defense, called effector-triggered immunity (ETI), to recognize the presence of pathogen effectors and inhibit colonization (8). ETI relies on resistance (R) proteins that act as receptors to directly or indirectly recognize effector molecules. ETI is associated with the hypersensitive response (HR), a rapid localized programmed cell death, which has the effect of limiting the development of a pathogen at the site of attack. The intensity and timing of the HR varies in different host-pathogen interactions $(2,54)$. Harpin-induced gene 1 (Hinl) is considered an HR marker gene because it was first reported to be highly induced by bacterial pathogenesis proteins and effectors in tobacco and tomato plants that underwent the HR (17). Other plant responses,

Corresponding author: D. A. Halterman;

E-mail address: dennis.halterman @ ars.usda.gov

* The $\boldsymbol{e}$-Xtra logo stands for "electronic extra" and indicates that the online version contains one supplemental figure. Figure 1 appears in color.

This article reports the results of research only. Mention of trade names or commercial products in this publication is solely for the purpose of providing specific information and does not imply recommendation or endorsement by the United States Department of Agriculture.

doi:10.1094/PHYTO-04-10-0119

This article is in the public domain and not copyrightable. It may be freely reprinted with customary crediting of the source. The American Phytopathological Society, 2011. callose deposition was negatively correlated with resistance levels in tested plants. Transcription patterns of pathogenesis-related (PR) genes $P R-1$ basic, $P R-2$ acidic, and $P R-5$ indicated that $P$. infestans inoculation induced transcription of these defense-related genes regardless of the host genotype; however, transcription was reduced in both the susceptible and partially resistant plants later in the infection process but remained elevated in the immune host. Most interestingly, transcription of the HRassociated gene Hinl was suppressed in both Katahdin and $R B$-transgenic Katahdin but not in R9 4 days after inoculation. Together, this suggests that suppression of certain defense-related genes may allow $P$. infestans to spread beyond the site of infection in the partially resistant host despite elicitation of hypersensitive cell death.

Additional keywords: effector triggered immunity. such as induction or suppression of defense-related genes, production of reactive oxygen species and antimicrobial compounds, and cell wall reinforcement also contribute to the restriction of pathogen spread (21). Deposition of callose at the cell wall is frequently associated with pathogen incompatibility and is thought to inhibit penetration into the cell $(28,41)$. In addition to localized resistance responses, plants have the capability of inducing defenses in areas distal to initial pathogen attack. This response is called systemic acquired resistance (SAR), and limits additional infections by diverse pathogen types (12). Some pathogenesis-related $(P R)$ genes, such as acidic and basic forms of $P R-1, P R-2, P R-3, P R-4$, and $P R-5$, are described as SAR markers because their coordinate induction correlates with the onset of SAR (56).

Potato late blight, caused by the oomycete pathogen Phytophthora infestans (Mont.) de Bary, was responsible for the Irish potato famine in the 1840 s and remains a great threat to potato production today. Each year, the costs of control and losses due to late blight total $>\$ 3$ billion worldwide (14). The most frequently used management strategy to control late blight is to spray fungicides repeatedly, which is expensive and negatively impacts the environment. Host resistance offers an alternative to chemical control, and wild potato species have provided rich resistance sources against late blight. Solanum demissum is a hexaploid Mexican species from which $11 R$ genes have been identified or cloned and have subsequently been used extensively in potato breeding for late blight resistance $(37,49,57)$. However, virulent races of $P$. infestans have rapidly overcome a majority of the $R$ genes from $S$. demissum in most potato-growing regions $(14,15$, 57 ). In contrast, another late blight $R$ gene, $R B$ (also known as Rpi-blb1), cloned from diploid wild potato species $S$. bulbocastanum, confers broad-spectrum resistance to multiple isolates of the pathogen due to the almost ubiquitous presence of the corresponding effector IPI-O $(7,46,50,53)$. $R B$ belongs to the 
largest class of characterized $R$ genes, those that encode putatively cytoplasmic proteins with nucleotide binding sites (NBs) and leucine-rich repeats (LRRs) (46,50). The $P$. infestans effector IPI-O $(43,52)$ is recognized by $\mathrm{RB}$ and elicits the HR upon recognition (53). Somatic fusions and transgenic plants containing $R B$ gene are highly resistant to late blight $(20,46,50)$. However, the $R B$ resistance phenotype is distinctive in that it confers partial resistance rather than immunity $(20,46)$. Therefore, it is essential to study the mechanism of $R B$-mediated $P$. infestans resistance in order to help us understand how $R B$ works and to utilize this unique gene in potato-breeding programs.

Previous cytological examinations of interactions between potato and $P$. infestans have indicated that $R$ genes have the capability of leading to localized cell death responses and prevention of pathogen growth $(13,16,25,54,58)$. Responses such as callose deposition have been observed in both compatible and incompatible $P$. infestans-potato interactions and are likely part of a nonspecific resistance mechanism $(10,16,54,58)$. In this study, we compared the $R B$-mediated late blight partial resistance phenotype with both susceptible and immune hosts in the hopes of understanding more about the responses that occur after $R B$ activation. We hypothesized that host defense responses would be quickest and strongest in the immune host, followed by the partially resistant host, and slowest and weakest in a susceptible host. To test this hypothesis, we monitored infection processes and HR development, detected callose deposition in each host during $P$. infestans infection, and compared the dynamics of transcription of PR- and HR-associated genes.

\section{MATERIALS AND METHODS}

Plant materials, pathogen isolates, and inoculation. To compare the different responses to $P$. infestans, the following $S$. tuberosum hosts were chosen: $S$. tuberosum cv. Katahdin, $R B$ transgenic potato line SP951 (cv. Katahdin plus a single copy of $R B$ ) (20), and $S$. tuberosum containing the $R 9$ resistance gene introgressed from $S$. demissum. All potato plants were propagated from cuttings and maintained in the greenhouse, which was set for $18 \mathrm{~h}$ of daylight, a daytime temperature of 17 to $19^{\circ} \mathrm{C}$, and a nighttime temperature of 13 to $15^{\circ} \mathrm{C}$. P. infestans strain $208 \mathrm{~m} 2$ was kindly provided by Dr. F. Mauch (University of Friberg, Switzerland) (45) and was used to inoculate all hosts. This strain is known to be avirulent on R9 plants (S. Wielgus and J. Jiang, unpublished).

Three inoculation methods were used in this study. One was a humid greenhouse, whole-plant resistance assay, which was performed to evaluate the resistance of the three potato lines (20). Four-week-old potato plants from cuttings were placed in an environmentally controlled growth chamber at the University of Wisconsin-Madison Biotron $6 \mathrm{~h}$ prior to inoculation. The mist chamber held a 24 -h relative humidity $>90 \%$, an 18 -h light period, a daytime temperature of 17 to $19^{\circ} \mathrm{C}$, and nighttime temperature of 13 to $15^{\circ} \mathrm{C}$. The plants were spray inoculated with sporangial suspensions of $P$. infestans strain $208 \mathrm{~m} 2$ at a concentration of 75,000 sporangia/ml. To obtain sporangia, mycelia growing on Rye A media were flooded with sterilized water and gently rubbed with a sterile glass rod. The late blight resistance score was determined by visual inspection of the plants 10 days after inoculation: $0=100,1=>90,2=81$ to $90,3=71$ to $80,4=61$ to $70,5=41$ to $60,6=26$ to $40,7=11$ to 25 , and $8=<10 \%$ infected tissue (9). An average score for resistance was determined using two replicates of each potato line from three independent inoculation experiments. Statistical analysis was performed using SAS v9.1.3 for Windows (SAS Institute Inc., Cary, NC). Another inoculation method was a dip inoculation assay. Detached leaflets were soaked in a $P$. infestans sporangia solution $(75,000$ sporangia/ml) for $30 \mathrm{~s}$, then incubated in a tissue culture box with water agar (day and night temperatures of 22 and $15^{\circ} \mathrm{C}$, respectively, with $18 \mathrm{~h}$ of light). The third inoculation method was drop inoculation. Whole plants were placed in a mist chamber, and leaflets of the fourth and fifth leaves below the uppermost fully expanded leaf were inoculated with two $10-\mu \mathrm{l}$ drops of $P$. infestans sporangia solution $(75,000$ sporangia/ml $)$ or water on both sides of the midvein, on the lower surface of the leaf, in approximately the same location. Separate plants were used for water and $P$. infestans inoculations. Leaf discs $\left(0.4 \mathrm{~cm}^{2}\right)$ were harvested from the inoculation sites for RNA preparation.

Cloning of IpiO from $P$. infestans strain $208 \mathrm{~m} 2$ and Nicotiana benthamiana infiltration. Genomic DNA of $P$. infestans was isolated using a FastDNA SPIN for Soil Kit (MP Biomedicals, LLC, OH). Using this DNA as a template, IpiO was amplified using Platinum polymerase chain reaction (PCR) SuperMix High Fidelity (Invitrogen, Carlsbad, CA) and a pair of oligonucleotide primers: RD6F (5'-CGCATCGATGGTTT CATCCAATCTCAACACCGCCG-3') and RD6R (5'-GATGC GGCCGCTATACGATGTCATAGCATGACA-3'). The PCR conditions were $1 \mathrm{~min}$ at $94^{\circ} \mathrm{C}$ followed by 40 cycles of $15 \mathrm{~s}$ at $94^{\circ} \mathrm{C}$, $30 \mathrm{~s}$ at $55^{\circ} \mathrm{C}, 30 \mathrm{~s}$ at $68^{\circ} \mathrm{C}$, and $7 \mathrm{~min}$ at $68^{\circ} \mathrm{C}$. The PCR product was purified using a Wizard SV Gel kit (Promega Corp., Madison, WI) and ligated into pGEM-T Easy Vector (Promega Corp.), which was then transformed into Escherichia coli. Twenty colonies were randomly selected for sequencing analysis. The plasmid containing the PCR products was digested with $C l a \mathrm{I}$ and NotI and ligated into ClaI- and NotI-digested pGR106 vector (36), which was transformed into A. tumefaciens strain GV3101. A. tumefaciens GV3101 containing pGR106 with IpiO1, IpiO2, IpiO4, or INF1 served as controls $(33,53)$. After overnight incubation in a $28^{\circ} \mathrm{C}$ shaker, A. tumefaciens cells were harvested by centrifugation and resuspended in MMA induction buffer ( 1 liter of MMA $=1 \mathrm{~g}$ of MS salts, $1.95 \mathrm{~g}$ of MES, and $20 \mathrm{~g}$ of sucrose, $\mathrm{pH}$ 5.6) containing $200 \mu \mathrm{M}$ acetosyringone to a final optical density at $600 \mathrm{~nm}$ of 1.0. Suspensions were incubated for $3 \mathrm{~h}$ at room temperature prior to infiltration. $R B$-transgenic Nicotiana benthamiana was used to test the recognition of IPI-O (35). All the infiltrated plants were incubated in a growth chamber (day and night temperatures of 22 and $18^{\circ} \mathrm{C}$, respectively, with $16 \mathrm{~h}$ of light).

Lactophenol trypan blue staining and light microscopy. Hypersensitive cell death and the development of $P$. infestans were monitored $0,4,8,24,48,72$, and $120 \mathrm{~h}$ postinoculation by staining whole leaflets in trypan blue (2). The potato leaves were spray inoculated to runoff with a handheld sprayer in the Biotron mist chamber. Leaflets from the fourth and fifth leaves under the uppermost fully expanded leaf were sampled and placed in a lactophenol-trypan blue solution $\left(11.5 \mathrm{ml}\right.$ of $\mathrm{H}_{2} \mathrm{O}, 10 \mathrm{ml}$ of lactic acid, $10 \mathrm{ml}$ of glycerol, $10 \mathrm{ml}$ of water-saturated phenol, and $10 \mathrm{mg}$ of trypan blue). The leaflets were first vacuum infiltrated three times for $2 \mathrm{~min}$ each, with a 5-min interval between each vacuum, then boiled for 5 to $8 \mathrm{~min}$. The leaflets were then incubated in the same solution for 6 to $8 \mathrm{~h}$ at room temperature. Leaf tissue was cleared using chloral hydrate $(250 \mathrm{~g}$ per $100 \mathrm{ml}$ of $\mathrm{H}_{2} \mathrm{O}$ ) for 1 to 3 days, until clear. Chloral hydrate solution was replaced with fresh solution every other day. Cleared leaf tissue was observed using an Olympus BX-60 microscope with DIC optics.

Callose staining and microcopy. To monitor callose deposition, leaflets were soaked in a $P$. infestans sporangia solution $(75,000$ sporangia/ml) for $30 \mathrm{~s}$, then incubated in a tissue culture box with water agar (day and night temperatures of 22 and $15^{\circ} \mathrm{C}$, respectively, with $18 \mathrm{~h}$ light). Ten leaf discs of $0.4 \mathrm{~cm}^{2}$ were taken randomly from each leaflet $48 \mathrm{~h}$ postinoculation. Callose staining and visualization were performed as described previously (18). Callose area was measured with ImagePro 5.0 software (Media Cybernetics, Bethesda, MD). Independent experiments were performed three times. Data were analyzed using one-way analysis of variance using SAS 9.1.3 for Windows. 
RNA extraction and real-time reverse-transcription PCR. Four-week-old Katahdin, SP951, and R9 plants from greenhouse cuttings were drop inoculated with $P$. infestans or water in the Biotron mist chamber. Leaf discs $\left(0.4 \mathrm{~cm}^{2}\right)$ were taken from the inoculation sites from leaflets located on the fourth and fifth leaves below the uppermost fully expanded leaf at 0,48 , and $96 \mathrm{~h}$ after inoculation (hai). Leaflets were treated with either $P$. infestans or sterile water. Leaf discs from the same plant were pooled together for RNA extraction using a Total RNA Extraction Kit (Sigma-Aldrich, St. Louis) according the manufacturer's instructions. On-column DNase I was used to remove genomic DNA contamination. The concentration and integrity of the RNA were tested by electrophoresis. DNase-treated RNA $(1 \mu \mathrm{g})$ was reverse transcribed using a first-strand synthesis kit (Bio-Rad, Hercules, CA). cDNA was diluted 1:4 and $3 \mu$ l was used in a $25-\mu l$ PCR reaction containing $12.5 \mu \mathrm{l}$ of SYBR Green reverse-transcription (RT)-PCR supermix (Invitrogen), $8.5 \mu \mathrm{l}$ of $\mathrm{H}_{2} \mathrm{O}$, and $0.5 \mu \mathrm{l}$ each of $2.5 \mathrm{pmol}$ forward and reverse primers (Table 1). PCR was carried out in a Bio-Rad MyIQ thermocycler under the following conditions: an initial denaturation at $94^{\circ} \mathrm{C}$ for $3 \mathrm{~min}$, followed by 40 cycles of $15 \mathrm{~s}$ at $94^{\circ} \mathrm{C}$, and $30 \mathrm{~s}$ at the annealing temperature (Table 1), during which the fluorescence data were collected. Each sample was run in triplicate in addition to nontemplate controls containing water instead of cDNA. For all calculations, the average value was used. The presence of single amplification products was verified using a melt curve generated by plotting the rate of change of the relative fluorescence units (RFU) with time (T) $(-\mathrm{d}(\mathrm{RFU}) / \mathrm{dT})$ on the Y-axis versus the temperature on the Xaxis. Real-time RT-PCR products were subsequently purified by electrophoresis and ligated into pGEM-T Easy Vector (as above), followed by sequencing to confirm that the PCR products were the target genes. Elongation factor $1 \alpha(\mathrm{EF} 1 \alpha)$ and 18 s RNA were used as reference genes in this study, which had been identified as the most suitable reference genes during potato- $P$. infestans interactions (39). Relative gene transcription levels were calculated using Genex 1.0 (http://www.bio-rad.com/amplification/), compared with the gene transcriptional level at 0 hai of the watertreated control of the same host genotype. The experiments were performed three times independently on different dates. Statistical analysis was performed with SAS 9.1.3 for Windows.

\section{RESULTS}

$P$. infestans strain $208 \mathrm{~m} 2$ contains effectors IpiO2 and AvrR9. In order to elucidate whether IpiO alleles exist in $P$. infestans strain $208 \mathrm{~m} 2$ and whether they are recognized by $R B$, primers from an IpiO-conserved region were used to amplify IpiO alleles from $P$. infestans strain $208 \mathrm{~m} 2$. Sequencing analysis revealed that only IpiO2 is present in $208 \mathrm{~m} 2$. Transient expression of IpiO2 in $R B$-transgenic $N$. benthamiana resulted in elici-

TABLE 1. Oligonucleotide primers used for real-time reverse-transcription polymerase chain reaction

\begin{tabular}{llc}
\hline $\begin{array}{l}\text { Primer } \\
\text { name }\end{array}$ & \multicolumn{1}{c}{ Primer sequence } & $\begin{array}{c}\text { Annealing } \\
\text { temperature } \\
\left({ }^{\circ} \mathrm{C}\right)\end{array}$ \\
\hline Hin 1F & 5'-CGTCCTCGGAGTCATTGC-3' $^{\prime}$ & 57 \\
Hin 1R & 5'-GCCTTGATACATACCTCTTGC-3' & $\ldots$ \\
PR-1 F & 5'-CTACAAATCAGGAGTTTACAAG-3' & 54 \\
PR-1 R & 5'-AATTAACAATGAGCCAATAGTC-3' & $\ldots$ \\
PR-2 F & 5'-TGATATTGACGAACTTGACGACAG-3' & 55 \\
PR-2 R & 5'-AGCGACCAGCACCAAACC-3' & $\ldots$ \\
PR-5 F & 5'-AGTCTGGTGCTGGGAATAAC-3' & 55 \\
PR-5 R & 5'-CCTTACCTTGGAAATCAGTAGTG-3' & $\ldots$ \\
EF1 $\alpha$ F & 5'-GGAGAGTTCTGAGACCATCG-3' & 56 \\
EF1 $\alpha$ R & 5'-CGGAGACGGAGGACAAGG-3' & $\ldots$ \\
18s F & 5'-GGGCATTCGTATTTCATAGTCAGA-3' & 52.5 \\
$18 s \mathrm{R}$ & 5'-CGGTTCTTGATTAATGAAAACATCCT-3' $^{\prime}$ & $\ldots$ \\
\hline
\end{tabular}

tation of the HR (Supplementary Figure 1). Spray inoculation of R9 potato plants with a $208 \mathrm{~m} 2$ sporangia suspension led to microscopic HR lesions on leaves (data not shown), confirming recognition of the corresponding effector and elicitation of resistance.

$\boldsymbol{R} B$-containing plants exhibit a partial resistance phenotype. Late-blight-susceptible $S$. tuberosum cv. Katahdin, transgenic cv. Katahdin containing a single copy of $R B$ (SP951), and potato containing the $R 9$ resistance gene were spray inoculated with a $P$. infestans sporangia suspension and incubated under humid greenhouse conditions. Plants were scored for resistance 10 days after inoculation (dai) (Table 2). Katahdin plants were highly susceptible and lost almost all leaves 10 dai, resulting in a resistance score of $2.0 \pm 0.8$. In contrast, $R B$-transgenic SP951 plants showed only minor disease symptoms and allowed the pathogen to sporulate and spread to a small degree by 10 dai, leading to a score of $5.1 \pm 0.9$. On leaves of R9 plants, macroscopic HR lesions were observed 3 dai and expansion of HR lesions was not observed at later time points; however, some chlorosis was observed on the lower leaves 10 dai. The resistance score of R9 plants 10 dai was $7.1 \pm 0.7$. Statistical analysis of the scores revealed a difference between R9, SP951, and Katahdin plants (Katahdin versus SP951, $P<0.001$; Katahdin versus R9, $P<$ 0.001 ; and R9 versus SP951, $P=0.001$ ).

Hypersensitive cell death is associated with both late blight immunity and partial resistance. To monitor pathogen growth and hypersensitive plant cell death, inoculated leaflets of Katahdin, SP951, and R9 were stained with lactophenol trypan blue at 4, 8, 24, 48, 72, and 120 hai with $P$. infestans. No growth of $P$. infestans or cell death was detected in any potato host 4 hai. At the time point 8 hai, a variety of $P$. infestans life stages were observed: some zoospores had encysted, some had formed haustoria, and some had developed hyphae along the anticlinal cell wall area of host epidermal cells (Fig. 1A) or under the epidermal cells (Fig. 1B) in Katahdin plants. In Katahdin, no cell death was detected earlier than 72 hai. However, after $72 \mathrm{~h}$, Katahdin cells in contact with $P$. infestans began to collapse and macroscopic lesions consistent with disease symptoms were observed (data not shown). In contrast, by $24 \mathrm{~h}$, the HR in R9 plants had completely enveloped $P$. infestans infection sites. Responses, including single epidermal cell death (Fig. 1C) and multicellular cell death in the mesophyll (Fig. 1D), were observed in R9 leaflets and effectively limited the spread of $P$. infestans to the infection sites. Similar to R9 leaflets, an HR was observed in $R B$-containing SP951. In SP951 leaflets, we observed that $P$. infestans sometimes attempted penetration from an anticlinal cell wall area eliciting single epidermal cell death. In other cases, hyphae penetrated epidermal cells and continued growing into the mesophyll cell layer, causing a multicellular response (Fig. 1E). In these plants, we also observed $P$. infestans zoospores attached to trichomes, with growth inside the host cell. However, when the hyphae attempted penetration into one or two epidermal cells, the related epidermal cells died. Most importantly, the HR in $R B$ containing plants was not completely effective in restricting the spread of $P$. infestans. Occasionally, hyphae escaped HR lesions and grew beyond (Fig. 1F). In all the three potato hosts, $P$. infestans was able to occasionally penetrate the epidermis and reach the mesophyll.

TABLE 2. Resistance scores of Katahdin, SP951, and R9 plants after inoculation with Phytophthora infestans

\begin{tabular}{lc}
\hline Host genotype & Resistance score $^{\mathrm{a}}$ \\
\hline Katahdin & $2.0 \pm 0.8$ \\
Katahdin + RB (SP951) & $5.1 \pm 0.9$ \\
R9 & $7.1 \pm 0.7$ \\
\hline
\end{tabular}

a Plants were scored 10 days after inoculation. The late blight resistance score was calculated based on observation of diseased leaf tissue: $0=100 \%$ diseased tissue and $8=<10 \%$ diseased tissue. 
Callose deposition is inversely correlated with resistance levels. In order to determine whether the three host genotypes elicited callose deposition differently in response to $P$. infestans inoculation, 10 leaf discs of $0.4 \mathrm{~cm}^{2}$ were taken randomly from dip-inoculated leaflets of each host 48 hai. The number of callose deposition spots, the average size of each spot, and the total area of callose deposition from each potato host were counted and measured (Table 3). Determination of the total area of callose deposition spots from 10 randomly selected leaf discs from each potato host revealed that Katahdin displayed the largest area of callose deposition, followed by $R B$-transgenic SP951. R9 leaves had the smallest area of callose deposition. Statistical analysis of the total areas showed that the three hosts differed from each other (Katahdin versus SP951, $P=0.002$; Katahdin versus R9, $P<0.001$; and R9 versus SP951, $P=0.036$ ). The number of cells producing callose was also different among genotypes. Analysis revealed a difference in the number of callose deposition spots between Katahdin and R9 plants $(P<0.001)$ as well as Katahdin and SP951 $(P=0.005)$, and weak evidence supported a difference between SP951 and R9 plants $(P=0.058)$. The average size of each callose deposition spot was similar for all potato genotypes. No callose deposition was detected in water-treated leaves.

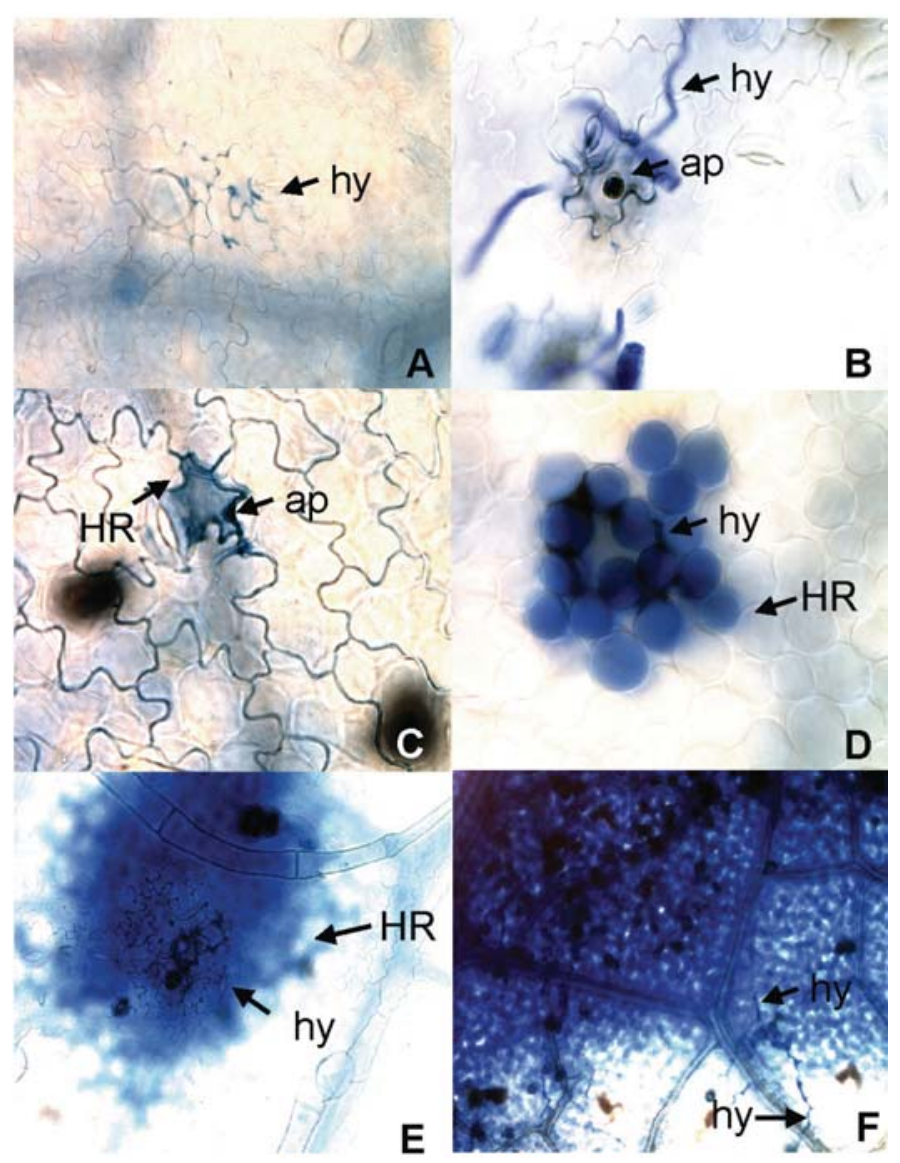

Fig. 1. Cytological characterization of three potato hosts with different resistance levels to Phytophthora infestans. A to B, Susceptible Solanum tuberosum cv. Katahdin. A, Growth of $P$. infestans in anticlinic cell wall areas causing no cell death. B, Penetration of $P$. infestans into an epidermal cell and development of hyphae beneath the epidermis. Photos were taken $8 \mathrm{~h}$ postinoculation (hpi), $\times 400$ magnification. $\mathbf{C}$ to $\mathbf{D}$, Immune potato containing the $R 9$ resistance gene. $\mathbf{C}$, Single-cell necrosis in response to the invasion of $P$. infestans. Photo was taken $8 \mathrm{hpi}, \times 400$ magnification. D, Multicellular necrosis of mesophyll cells in response to $P$. infestans. Note that $P$. infestans hyphae (very dark blue) are constrained to the region inside the necrotic region. Photo was taken 24 hpi, $\times 400$ magnification. E to F, Transgenic cv. Katahdin containing a single copy of $R B$ (SP951). E, Multicellular necrosis of mesophyll cells in response to $P$. infestans. F, Growth of $P$. infestans hyphae (black arrows) beyond the necrotic region. Photos were taken $120 \mathrm{hpi}, \times 100$ magnification.
Intensity and timing of gene expression patterns differentiates partial resistance from immunity. Real-time quantitative RT-PCR was used to determine whether the transcription patterns of Hin1, PR-1 basic (PR-1b), PR-2 acidic (PR-2a), and PR-5 differed among potato lines after $P$. infestans inoculation. Our results show that Hinl transcription was induced by $P$. infestans in all three potato hosts compared with water-inoculated plants at 48 and 96 hai (Katahdin: 48 hai $P=0.005,96$ hai $P<0.001$; R9: 48 hai $P=0.056,96$ hai $P=0.064$; and SP951: 48 hai $P=0.026$, 96 hai $P=0.034$ ) (Fig. 2). Relative gene expression levels are summarized in Table 4. Although significant induction of Hinl was detected in all lines, the patterns of gene transcription differentiated R9 from Katahdin and SP951 in P. infestans-inoculated leaves. Hin1 transcript levels were similar in all three hosts 48 hai; however, they increased in R9 at 96 hai $(P=0.033)$ but decreased in Katahdin and SP951. The gene was induced slightly in water-treated R9 plants 96 hai but the transcription level was lower than in the $P$. infestans-inoculated R9 plant $(P<0.001)$.

$P R-1 b$ was also induced in all three potato hosts after $P$. infestans inoculation at 48 and 96 hai (Katahdin: 48 hai $P=$ $0.011,96$ hai $P<0.001$; R9: 48 hai $P=0.043,96$ hai $P=0.011$; and SP951: 48 hai $P=0.001,96$ hai $P=0.001)$. Transcript abundance increased to the highest levels at 96 hai in all plants. However, the magnitude of transcript escalation between 48 and 96 hai differentiated the three host phenotypes because $P R-1 b$ transcripts increased in abundance in R9 plants $(P<0.001)$ much more than in Katahdin or SP951. In a comparison of the nontransgenic and transgenic plants containing $R B, P$. infestans inoculation led to higher $P R-1 b$ transcript accumulation in SP951 than in Katahdin at both 48 and 96 hai (48 hai, $P=0.028$; 96 hai, $P<0.001)$. The gene was induced in water-treated R9 and SP951 plants at 48 hai $(P<0.001)$ but each was much lower than in the $P$. infestans-inoculated plants at the same time point $(\mathrm{R} 9 P=$ 0.043; SP951 $P<0.001)$.

$P R-2 a$ transcript accumulation patterns were similar to those of $P R-1 b$, because it was induced in all three potato hosts after $P$. infestans inoculation compared with water-inoculated plants at both time points after inoculation (Katahdin: 48 hai $P=0.029,96$ hai $P=0.002$; R9: 48 hai $P=0.001,96$ hai $P=0.008$; and SP951: 48 hai $P=0.014,96$ hai $P=0.001)$. Again, patterns of $P R-2 a$ accumulation differentiated R9 plants from Katahdin and SP951 between the 48 and 96 hai time points. Transcription of $P R-2 a$ did not change significantly in Katahdin and SP951 during this time whereas transcription increased in R9 plants $(P=0.004)$. In $P$. infestans-inoculated plants, the gene transcription levels were also significantly higher in SP951 than in Katahdin (48 and 96 hai, $P=$ $0.002)$. The gene was also induced slightly in water-treated $R 9$ and SP951 plants 48 hai $(P<0.001)$ but the transcript levels were lower than those in $P$. infestans-inoculated plants.

Transcription patterns of $P R-5$ revealed an increase in transcript abundance after $P$. infestans inoculation at 48 and 96 hai (Katahdin: 48 hai $P<0.001$, 96 hai $P<0.001$; R9: 48 hai $P=$ $0.020,96$ hai $P=0.036$; and SP951: 48 hai $P=0.013$, 96 hai $P=$ $0.010)$. Transcript accumulation in R9 plants continued to increase considerably between 48 and 96 hai $(P=0.001)$ whereas transcript abundance decreased in Katahdin and SP951 during the same time period. Similar to the other PR genes, $P R-5$ transcript levels were significantly higher in SP951 than that in Katahdin at

TABLE 3. Summary of the number of callose deposition spots, average size of each spot, and the total area of callose deposition in each potato host $48 \mathrm{~h}$ after inoculation

\begin{tabular}{lccl}
\hline Parameters & Katahdin & SP951 & R9 \\
\hline Number of spots & $25 \pm 5$ & $10 \pm 4$ & $1 \pm 1$ \\
Average size $\left(\mathrm{mm}^{2}\right)$ & $0.106 \pm 0.018$ & $0.117 \pm 0.029$ & $0.126 \pm 0.036$ \\
Total area $\left(\mathrm{mm}^{2}\right)$ & $2.584 \pm 0.413$ & $0.989 \pm 0.201$ & $0.137 \pm 0.118$ \\
\hline
\end{tabular}

a Total from 10 leaf discs of $0.4 \mathrm{~cm}^{2}$ each. 
both time points (48 hai, $P=0.002 ; 96$ hai, $P=0.031$ ). $P R-5$ transcripts increased in abundance in water-treated R9 and SP951 at 48 hai $(P<0.001)$ but levels were lower than after $P$. infestans inoculation at 96 hai.

\section{DISCUSSION}

Late blight continues to be a devastating potato disease worldwide, and host resistance remains the most attractive long-term management strategy for control of disease outbreaks. In recent years, intensive studies have been performed on the interaction between potato and $P$. infestans, focusing on responses of susceptible hosts $(4,44)$, partially resistant hosts $(55)$, and comparison of susceptible and partially resistant hosts (1). In this study, we performed cytological and molecular characterization of $R B$ mediated partial resistance in transgenic plants compared with susceptibility in nontransformed controls and host immune responses mediated by the $R 9$ gene derived from $S$. demissum. R9 is derived from a set of Black's differentials $(5,37)$ and, like Katahdin, is considered a $S$. tuberosum cultivar. It is possible that differences in the genetic backgrounds between SP951 and R9 might impact differences in resistance responses. Therefore, our analysis of gene transcription was focused on differences in expression patterns rather than quantitative differences between hosts. Our analysis resulted in clear differentiation of defenserelated gene transcription patterns between $\mathrm{R} 9$ and partially resistant SP951 although both plants were able to elicit hypersensitive cell death. Differences in HR and callose deposition phenotypes were observed between Katahdin and SP951, indicating that they are related to the presence or absence of $R B$.

The HR plays an important role in all forms of host and nonhost resistance to $P$. infestans (32). Typically, the HR is associated with other responses, which cooperate to restrict pathogen growth. However, cell death and resistance can be decoupled, indicating that multiple host responses are required for immunity
$(3,11,29,59,60)$. We found that the $R B$ resistance gene was sufficient to induce an $\mathrm{HR}$ within the first $8 \mathrm{~h}$ after $P$. infestans inoculation. This response is comparable with that of plants containing $R 9$, which mediates immunity, suggesting that this time frame is critical for initiation of resistance. Presumably, the earlier the HR appears, the more effective it will be at preventing $P$. infestans growth. Because the timing of $\mathrm{HR}$ induction in both $R B$ plants and immune $\mathrm{R} 9$ plants was the same, we proposed that partial resistance genes, such as $R B$, use molecular mechanisms similar to $R$ genes that confer immunity but may differ in the timing or intensity of eliciting defense responses. However, the escape of hyphae beyond the HR lesions and limited infection in $R B$-containing plants demonstrated that the HR alone is not capable of stopping hyphal growth. The phenotype we have observed is similar to trailing HR reported in some partially resistant Solanum plants $(2,54)$. In $S$. bulbocastanum accessions that are completely resistant to $P$. infestans, $R B$ cooperates with other $R$ genes, including $R p i-b l b 2$ and $R p i-b l b 3$, to coordinate activities to induce faster and more complete defense responses. In support of previous results from our laboratory, we can conclude that, in SP951 (Katahdin $+R B$ ), $R B$ alone is not sufficient for immunity and further demonstrates that elicitation of the HR is not always strictly correlated with complete resistance to pathogens.

A possible reason that $R B$ confers partial resistance instead of immunity is because of an inability for this protein to elicit defense responses other than the HR after recognition of the pathogen. Host responses to pathogens typically involve the activation and suppression of numerous genes, and the difference among the hosts with different resistance levels is quantitative and temporal, rather than qualitative $(38,47)$. We hypothesized that induction of Hinl and selected PR genes would occur most quickly and intensively in the immune R9 plants and more slowly and mildly in susceptible cv. Katahdin. We expected partially resistant plants with $R B$ to exhibit an intermediate phenotype.
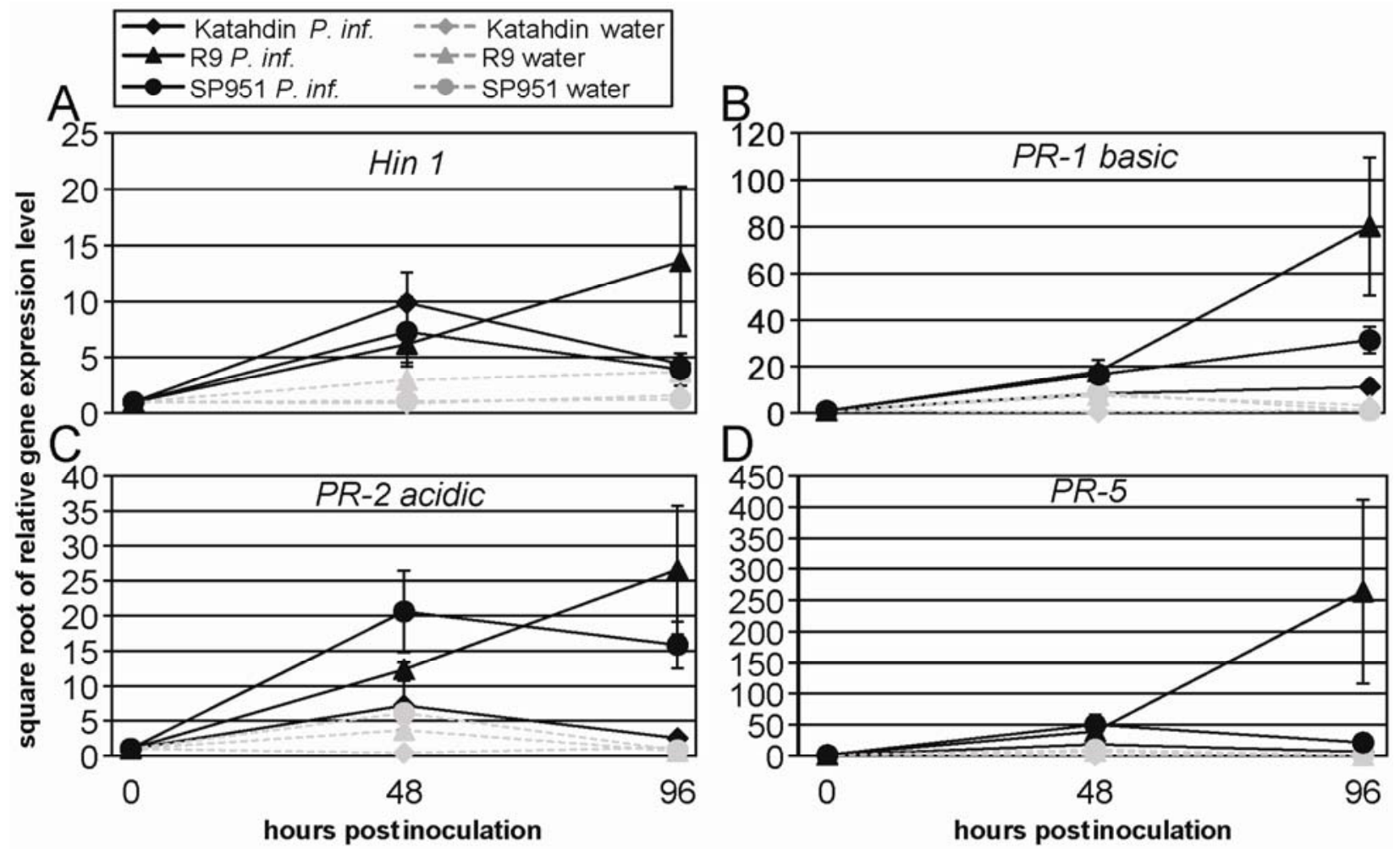

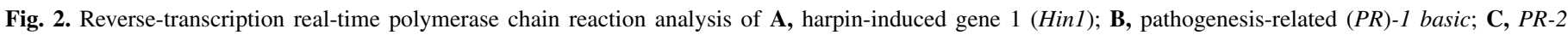

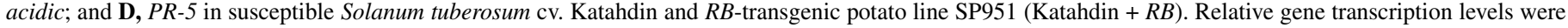

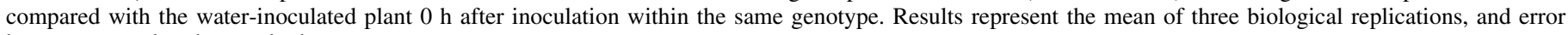
bars correspond to the standard error. 
Instead, we found that transcripts of Hinl did not increase significantly between 48 and 96 hai in either susceptible Katahdin or partially resistant SP951 but continued to increase during the same time period in R9. Transcript levels of Hinl increased in all three genotypes at 0 to 48 hai, suggesting that Hinl expression is linked to basal defense responses, and was subsequently reduced in Katahdin and SP951 plants at 48 to 96 hai but continued to increase in R9 plants. Similar patterns of expression were observed with $P R-2 a$ and $P R-5$. However, an increase in $P R$ gene expression correlated nicely with the presence of partial resistance 96 hai because transcript levels of $P R-1 b, P R-2 a$, and $P R-5$ were higher in SP951 compared with Katahdin. Together, our results indicate that $P$. infestans may be able to suppress Hinl and PR gene transcription in both Katahdin and SP951 and is less capable of suppressing PR gene transcription in R9. If P. infestans is able to suppress the HR in later stages of the infection process even when $R B$ is present, this could explain why the pathogen is able to spread beyond HR lesions in SP951. The functions of PR proteins have been associated with antifungal activities, which suggest a role in active defense against some pathogens. The PR-2 family has been found to contain $\beta-1,3$ glucanase activity, and PR-5 is involved in osmo-permeabiliztion of fungal plasma membranes (51). Although the molecular mechanism of PR-1 family members remains unclear, it has been demonstrated that PR-1 proteins inhibit zoospore germination and mycelial growth of $P$. infestans during infection of tomato (40). In our study, the induction of $P R-1 b, P R-2 a$, and $P R-5$ in resistant potato genotypes implies a possible role of these genes in resistance to $P$. infestans; however, further studies are required to make this determination. Different types of pathogens have the ability to suppress host defense $(22,26,30)$. Therefore, we were not surprised that expression of $P R$ genes was suppressed by the pathogen in Katahdin. However, $P R$ gene transcription was also curtailed in SP951, especially when compared with R9, between 48 and 96 hai, suggesting pathogen suppression of transcription even in the presence of RB.

Callose functions in plant development and its formation and deposition are induced by mechanical wounding, physiological stress, and pathogen infection (27). It has been postulated that callose deposition acts as a physical barrier to impede microbial penetration (24). However, reports both supporting and rejecting this idea have been published $(28,41,48,61)$. In our study, the total area of callose deposition was inversely correlated with resistance. It appears likely, therefore, that callose deposition is not effective in preventing the entry of $P$. infestans even when potato $R$ genes with immunity or partial resistance phenotypes are activated, and is instead only associated with pathogen spread. These results are consistent with assays of $P$. infestans immunity and partial resistance from other or unknown Solanaceous sources of resistance (54).

Expression of $R B$ is closely correlated with the strength of the resistance response because transgenic plants with multiple integration events are more resistant than those with fewer copies of $R B(6,34)$. SP951, the transgenic potato used in our assays, is transgenic $S$. tuberosum cv. Katahdin containing a single copy of the $R B$ gene. It is possible that an increase in $R B$ expression would lead to a more rapid and stronger response in the host, resulting in responses that more closely resemble immunity. Future experiments using plants with a wide range of $R B$ transcription levels might help us understand the relationship between $\mathrm{RB}$ expression and resistance as well as the interactions that take place between RB and IPI-O effectors. We have shown here that $R B$-containing plants respond similarly to immune hosts through elicitation of an HR but differ in the transcription patterns for the HR-related gene Hinl and the PR genes $P R-1 b, P R-2 a$, and $P R-5$. Callose deposition was inversely correlated with resistance, suggesting that it may be a response of basal defense and not directly involved in resistance. Expression patterns of defenserelated genes also suggested that $P$. infestans might be able to suppress responses in both susceptible Katahdin and partially resistant SP951. In support of this, we have shown separately that $\mathrm{RB}$ is susceptible to suppression of HR elicitation by variants of the IPI-O effector family (19), indicating a complex and dynamic interface between potato $R$ gene products and $P$. infestans effectors. Suppression of defense responses, such as PR gene expression, and the ability to outgrow a multicellular hypersensitive cell death response could explain the partial resistance phenotype that has been repeatedly observed in plants with the $R B$ gene. Despite the fact that $R B$-mediated resistance is not complete, this gene remains a valuable trait because it confers broad-spectrum resistance to multiple isolates of $P$. infestans. Experiments comparing responses of $R B$-containing hosts to

TABLE 4. Relative expression of harpin-induced gene 1 (Hin1), pathogenesis-related (PR)-1 basic, PR-2 acidic, and PR-5 in three potato hosts after Phytophthora infestans or water inoculation compared with water-inoculated plants $0 \mathrm{~h}$ after inoculation (hai) within potato genotypes ${ }^{\mathrm{a}}$

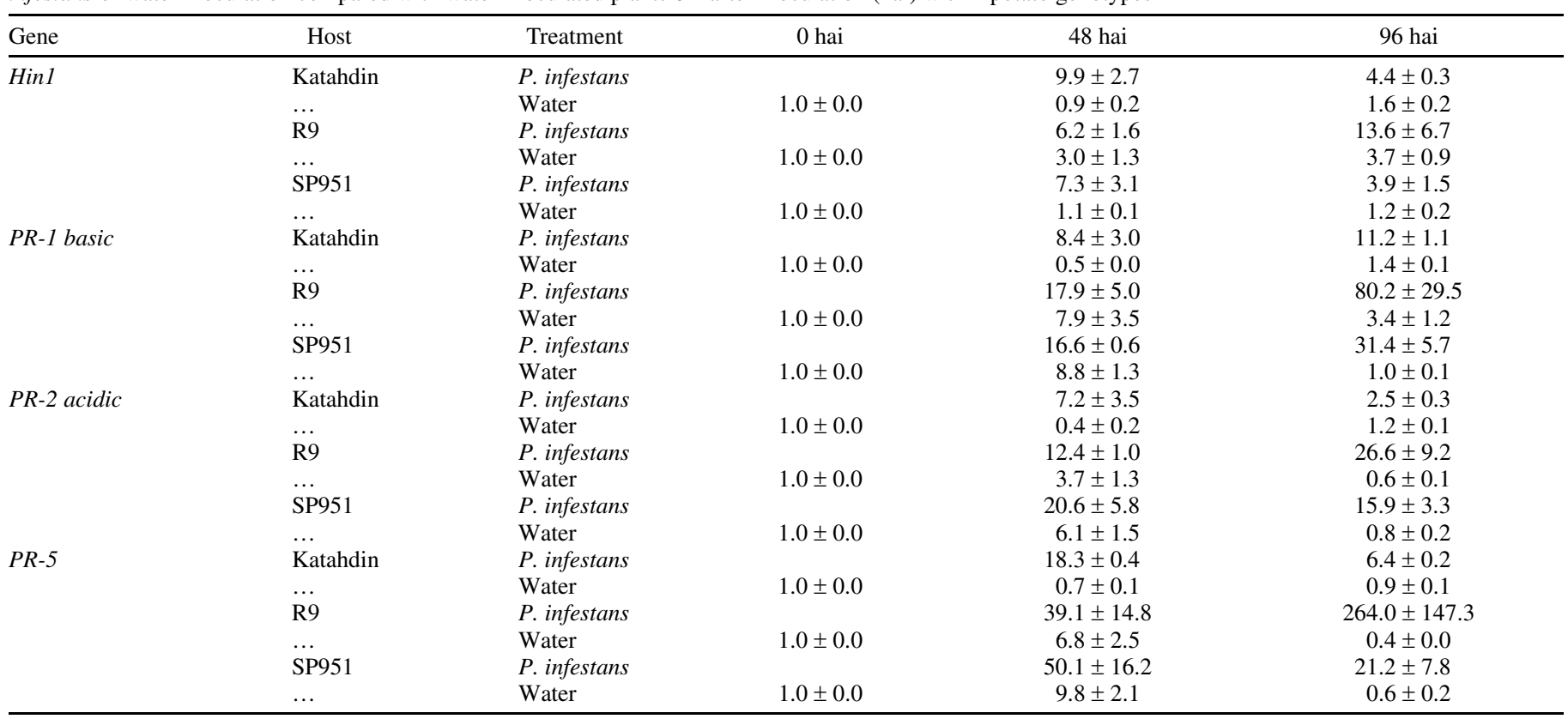

a Relative transcription level of each gene is represented as the mean \pm standard deviation. 
different $P$. infestans isolates with variable degrees of aggressiveness (19), would help elucidate how $R B$ mediates resistance or is suppressed by IPI-O activity. Additionally, using multiple immune pathosystems, such as $R 3 a / A v r 3 a$, to compare with $R B$ meditated resistance would help us understand the differences between partial and immune resistance responses. Our results indicate that timing of the HR and PR gene expression may play a critical role in the resistance response. However, further work needs to be done to determine what responses are hallmarks for partial and immune resistance responses to potato late blight.

\section{ACKNOWLEDGMENTS}

We thank the United States Department of Agriculture and the University of Wisconsin Department of Plant Pathology for providing salaries and research support, and G. Middleton for expert technical assistance.

\section{LITERATURE CITED}

1. Avrova, A. O., Taleb, N., Rokka, V. M., Heilbronn, J., Campbell, E., Hein, I., Gilroy, E. M., Cardle, L., Bradshaw, J. E., Stewart, H. E., Fakim, Y. J., Loake, G., and Birch, P. R. J. 2004. Potato oxysterol binding protein and cathepsin $\mathrm{B}$ are rapidly up-regulated in independent defence pathways that distinguish $R$ gene-mediated and field resistances to Phytophthora infestans. Mol. Plant Pathol. 5:45-56.

2. Becktell, M. C., Smart, C. D., Haney, C. H., and Fry, W. E. 2006. Hostpathogen interactions between Phytophthora infestans and the Solanaceous hosts Calibrachoa $\times$ hybridus, Petunia $\times$ hybrida, and Nicotiana benthamiana. Plant Dis. 90:24-32.

3. Bendahmane, A., Kanyuka, K., and Baulcombe, D. C. 1999. The Rx gene from potato controls separate virus resistance and cell death responses. Plant Cell 11:781-792.

4. Beyer, K., Binder, A., Boller, T., and Collinge, M. 2001. Identification of potato genes induced during colonization by Phytophthora infestans. Mol. Plant Pathol. 2:125-134.

5. Black, W., Mastenbroek, C., Mills, W. R., and Peterson, L. C. 1953. A proposal for an international nomenclature of races of Phytophthora infestans and of genes controlling immunity in Solanum demissum derivatives. Euphytica 2:173-178.

6. Bradeen, J. M., Iorizzo, M., Mollov, D. S., Raasch, J., Kramer, L. C., Millett, B. P., Austin-Phillips, S., Jiang, J., and Carputo, D. 2009. Higher copy numbers of the potato $R B$ transgene correspond to enhanced transcript and late blight resistance levels. Mol. Plant-Microbe Interact. 22:437-446.

7. Champouret, N., Bouwmeester, K., Rietman, H., van der Lee, T., Maliepaard, C., Heipink, A., van de Vondervoort, P. J. I., Jacobsen, E., Visser, R. G. F., van der Vossen, E. A. G., Govers, F., and Vleeshouwers, V. G. A. A. 2009. Phytophthora infestans isolates lacking class I ipiO variants are virulent on Rpi-blbl potato. Mol. Plant-Microbe Interact. 22:1535-1545.

8. Chisholm, S. T., Coaker, G., Day, B., and Staskawicz, B. J. 2006. Hostmicrobe interactions: shaping the evolution of the plant immune response. Cell 124:803-814.

9. Colton, L. M., Groza, H. I., Wielgus, S. M., and Jiang, J. 2006. Markerassisted selection for the broad-spectrum potato late blight resistance conferred by gene $R B$ derived from a wild potato species. Crop Sci. 46:589-594.

10. Cuypers, B., and Hahlbrock, K. 1988. Immunohistochemical studies of compatible and incompatible interactions of potato leaves with Phytophthora infestans and of the nonhost response to Phytophthora megasperma. Can. J. Bot. 66:700-705.

11. del Pozo, O., and Lam, E. 1998. Caspases and programmed cell death in the hypersensitive response of plants to pathogens. Curr. Biol. 8:11291132.

12. Durrant, W. E., and Dong, X. 2004. Systemic acquired resistance. Annu. Rev. Phytopathol. 42:185-209.

13. Ferris, V. 1955. Histological study of pathogen-suscept relations between Phytophthora infestans and derivatives of Solanum demissum. Phytopathology 45:546-552.

14. Fry, W. 2008. Phytophthora infestans: the plant (and $R$ gene) destroyer. Mol. Plant Pathol. 9:385-402.

15. Fry, W. E., and Goodwin, S. B. 1997. Re-emergence of potato and tomato late blight in the United States. Plant Dis. 81:1349-1357.

16. Gees, R., and Hohl, H. 1988. Cytological comparison of specific (R3) and general resistance to late blight in potato leaf tissue. Phytopathology 78:350-357.
17. Gopalan, S., Wei, W., and He, S. Y. 1996. hrp gene-dependent induction of hin1: a plant gene activated rapidly by both harpins and the avrPto gene-mediated signal. Plant J. 10:591-600.

18. Halim, V. A., Eschen-Lippold, L., Altmann, S., Birschwilks, M., Scheel, D., and Rosahl, S. 2007. Salicylic acid is important for basal defense of Solanum tuberosum against Phytophthora infestans. Mol. Plant-Microbe Interact. 20:1346-1352.

19. Halterman, D., Chen, Y., Sopee, J., Berduo-Sandoval, J., and SánchezPérez, A. Competition between Phytophthora infestans effectors leads to increased aggressiveness on plant containing broad-spectrum late blight resistance. PLoS One. 5:e10536.

20. Halterman, D., Kramer, L. C., Weilgus, S., and Jiang, J. 2008. Performance of transgenic potato containing the late blight resistance gene $R B$. Plant Dis. 92:339-343.

21. Hammond-Kosack, K. E., and Jones, J. D. 1996. Resistance genedependent plant defense responses. Plant Cell 8:1773-1791.

22. Hauck, P., Thilmony, R., and He, S. Y. 2003. A Pseudomonas syringae type III effector suppresses cell wall-based extracellular defense in susceptible Arabidopsis plants. Proc. Natl. Acad. Sci. USA 100:8577-8582.

23. He, P., Shan, L., Lin, N.-C., Martin, G. B., Kemmerling, B., Nürnberger, T., and Sheen, J. 2006. Specific bacterial suppressors of MAMP signaling upstream of MAPKKK in Arabidopsis innate immunity. Cell 125:563575 .

24. Hematy, K., Cherk, C., and Somerville, S. 2009. Host-pathogen warfare at the plant cell wall. Curr. Opin. Plant Biol. 12:406-413.

25. Hohl, H., and Suter, E. 1976. Host-parasite interfaces in a resistant and a susceptible cultivar of Solanum tuberosum inoculated with Phytophthora infestans: leaf tissue. Can. J. Bot. 54:1956-1970.

26. Houterman, P. M., Cornelissen, B. J. C., and Rep, M. 2008. Suppression of plant resistance gene-based immunity by a fungal effector. PLoS Pathogen 4:e1000061.

27. Huckelhoven, R. 2007. Cell wall associated mechanisms of disease resistance and susceptibility. Annu. Rev. Phytopathol. 45:101-127.

28. Jacobs, A. K., Lipka, V., Burton, R. A., Panstruga, R., Strizhov, N., Schulze-Lefert, P., and Fincher, G. B. 2003. An Arabidopsis callose synthase, GSL5, is required for wound and papillary callose formation. Plant Cell 15:2503-2513.

29. Jakobek, J. L., and Lindgren, P. B. 1993. Generalized induction of defense responses in bean is not correlated with the induction of the hypersensitive reaction. Plant Cell 5:49-56.

30. Jamir, Y., Guo, M., Oh, H.-S., Petnicki-Ocwieja, T., Chen, S., Tang, X., Dickman, M. B., Collmer, A., and R. Alfano, J. 2004. Identification of Pseudomonas syringae type III effectors that can suppress programmed cell death in plants and yeast. Plant J. 37:554-565.

31. Jones, J. D. G., and Dangl, J. L. 2006. The plant immune system. Nature 444:323-329.

32. Kamoun, S., Huitema, E., and Vleeshouwers, V. G. 1999. Resistance to oomycetes: a general role for the hypersensitive response? Trends Plant Sci. 4:196-200.

33. Kamoun, S., van West, P., Vleeshouwers, V., de Groot, K. E., and Govers, F. 1998. Resistance of Nicotiana benthamiana to Phytophthora infestans is mediated by the recognition of the elicitor protein INF1. Plant Cell 10:1413-1425.

34. Kramer, L. C., Choudoir, M. J., Wielgus, S. M., Bhaskar, P. B., and Jiang, J. 2009. Correlation between transcript abundance of the $R B$ gene and the level of the $R B$-mediated late blight resistance in potato. Mol. PlantMicrobe Interact. 22:447-455.

35. Liu, Z., and Halterman, D. 2009. Analysis of proteins differentially accumulated during potato late blight resistance mediated by the $R B$ resistance gene. Physiol. Mol. Plant Pathol. 74:151-160.

36. Lu, R., Martin-Hernandez, A. M., Peart, J. R., Malcuit, I., and Baulcombe, D. C. 2003. Virus-induced gene silencing in plants. Methods 30:296-303

37. Malcolmson, J. F., and Black, W. 1966. New $R$ genes in Solanum demissum Lindl. and their complementary races of Phytophthora infestans (Mont.) de Bary. Euphytica 15:199-203.

38. Maleck, K., Levine, A., Eulgem, T., Morgan, A., Schmid, J., Lawton, K. A., Dangl, J. L., and Dietrich, R. A. 2000. The transcriptome of Arabidopsis thaliana during systemic acquired resistance. Nat. Genet. 26:403-410.

39. Nicot, N., Hausman, J.-F., Hoffmann, L., and Evers, D. 2005. Housekeeping gene selection for real-time RT-PCR normalization in potato during biotic and abiotic stress. J. Exp. Bot. 56:2907-2914.

40. Niderman, T., Genetet, I., Bruyere, T., Gees, R., Stintzi, A., Legrand, M., Fritig, B., and Mosinger, E. 1995. Pathogenesis-related PR-1 proteins are antifungal. Isolation and characterization of three 14-kilodalton proteins of tomato and of a basic PR-1 of tobacco with inhibitory activity against Phytophthora infestans. Plant Physiol. 108:17-27.

41. Nishimura, M. T., Stein, M., Hou, B.-H., Vogel, J. P., Edwards, H., and Somerville, S. C. 2003. Loss of a callose synthase results in salicylic acid- 
dependent disease resistance. Science 301:969-972.

42. Nomura, K., DebRoy, S., Lee, Y. H., Pumplin, N., Jones, J., and He, S. Y. 2006. A bacterial virulence protein suppresses host innate immunity to cause plant disease. Science 313:220-223.

43. Pieterse, C. M., van West, P., Verbakel, H. M., Brassé, P. W., van den Berg-Velthuis, G. C., and Govers, F. 1994. Structure and genomic organization of the ipiB and ipiO gene clusters of Phytophthora infestans. Gene 138:67-77.

44. Restrepo, S., Meyers, K. L., del Pozo, O., Martin, G. B., Hart, A. L., Buell, C. R., Fry, W. E., and Smart, C. D. 2005. Gene profiling of a compatible interaction between Phytophthora infestans and Solanum tuberosum suggests a role for carbonic anhydrase. Mol. Plant-Microbe Interact. 18:913-922.

45. Si-Ammour, A., Mauch-Mani, B., and Mauch, F. 2003. Quantification of induced resistance against Phytophthora species expressing GFP as a vital marker: Beta-aminobutyric acid but not BTH protects potato and Arabidopsis from infection. Mol. Plant Pathol. 4:237-248.

46. Song, J., Bradeen, J. M., Naess, S. K., Raasch, J. A., Wielgus, S. M., Haberlach, G. T., Liu, J., Kuang, H., Austin-Phillips, S., Buell, C. R., Helgeson, J. P., and Jiang, J. 2003. Gene RB cloned from Solanum bulbocastanum confers broad spectrum resistance to potato late blight. Proc. Natl. Acad. Sci. USA 100:9128-9133.

47. Tao, Y., Xie, Z. Y., Chen, W. Q., Glazebrook, J., Chang, H. S., Han, B., Zhu, T., Zou, G. Z., and Katagiri, F. 2003. Quantitative nature of Arabidopsis responses during compatible and incompatible interactions with the bacterial pathogen Pseudomonas syringae. Plant Cell 15:317330.

48. Ton, J., and Mauch-Mani, B. 2004. Beta-amino-butyric acid-induced resistance against necrotrophic pathogens is based on ABA-dependent priming for callose. Plant J. 38:119-130.

49. Umaerus, V., and Umaerus, M. 1994. Inheritance of resistance to late blight. Pages 365-401 in: Potato Genetics. J. E. B. Bradshaw and G. R. Mackay, eds. CAB International, Wallingford, UK.

50. van der Vossen, E., Sikkema, A., Hekkert, B. t. L., Gros, J., Stevens, P., Muskens, M., Wouters, D., Pereira, A., Stiekema, W., and Allefs, S. 2003. An ancient $R$ gene from the wild potato species Solanum bulbocastanum confers broad-spectrum resistance to Phytophthora infestans in cultivated potato and tomato. Plant J. 36:867-882.

51. van Loon, L. C., Rep, M., and Pieterse, C. M. J. 2006. Significance of inducible defense-related proteins in infected plants. Annu. Rev. Phytopathol. 44:135-162.

52. van West, P., de Jong, A. J., Judelson, H. S., Emons, A. M. C., and Govers, F. 1998. The ipiO gene of Phytophthora infestans is highly expressed in invading hyphae during infection. Fungal Genet. Biol. 23:126-138.

53. Vleeshouwers, V. G., Rietman, H., Krenek, P., Champouret, N., Young, C., Oh, S. K., Wang, M., Bouwmeester, K., Vosman, B., Visser, R. G., Jacobsen, E., Govers, F., Kamoun, S., and Van der Vossen, E. A. 2008. Effector genomics accelerates discovery and functional profiling of potato disease resistance and Phytophthora infestans avirulence genes. PLoS ONE 3:e2875.

54. Vleeshouwers, V. G., van Dooijeweert, W., Govers, F., Kamoun, S., and Colon, L. T. 2000. The hypersensitive response is associated with host and nonhost resistance to Phytophthora infestans. Planta 210:853-864.

55. Wang, B., Liu, J., Tian, Z., Song, B., and Xie, C. 2005. Monitoring the expression patterns of potato genes associated with quantitative resistance to late blight during Phytophthora infestans infection using cDNA microarrays. Plant Sci. 169:1155-1167.

56. Ward, E. R., Uknes, S. J., Williams, S. C., Dincher, S. S., Wiederhold, D. L., Alexander, D. C., Ahl-Goy, P., Metraux, J. P., and Ryals, J. A. 1991. Coordinate gene activity in response to agents that induce systemic acquired resistance. Plant Cell 3:1085-1094.

57. Wastie, R. L. 1991. Breeding for resistance. Pages 193-224 in: Phytophthora infestans: The Cause of Late Blight of Potato. D. S. Ingram and P. H. Williams, eds. Academic Press, San Diego, CA.

58. Wilson, U., and Coffer, M. 1980. Cytological evaluation of general resistance to Phytophthora infestans in potato foliage. Ann. Bot. 45:81-90.

59. Yu, I., Fengler, K. A., Clough, S. J., and Bent, A. F. 2000. Identification of Arabidopsis mutants exhibiting an altered hypersensitive response in gene-for-gene disease resistance. Mol. Plant-Microbe Interact. 13:277286.

60. Yu, I.-C., Parker, J., and Bent, A. F. 1998. Gene-for-gene disease resistance without the hypersensitive response in Arabidopsis dndl mutant. Proc. Natl. Acad. Sci. USA 95:7819-7824.

61. Yun, M. H., Torres, P. S., Oirdi, M. E., Rigano, L. A., GonzalezLamothe, R., Marano, M. R., Castagnaro, A. P., Dankert, M. A., Bouarab, K., and Vojnov, A. A. 2006. Xanthan induces plant susceptibility by suppressing callose deposition. Plant Physiol. 141:178-187. 